\title{
江戸時代後期の京都の町家における二条番衆の寄宿形態 THE BOARDING SYSTEM FOR NIJO-CASTLE CARETAKERS WITH MACHIYA IN THE END OF EDO PERIOD
}

\author{
丸山俊明* \\ Toshiaki MARUYAMA
}

\begin{abstract}
In the end of edo period, town people in Kyoto are obligated by Tokugawa Shogunate to accept and treat Nijo-castle caretakers (Nijo zaiban) in their machiya about few days. Town people in Kyoto have to prepared five or six room house for Nijo-castle caretakers. This paper aims to clear up the detail of this boarding system by investigation about town people's documents and concrete sample.
\end{abstract}

\section{Keywords : Kyoto, machiya, kishuku, Nijo-castle, nijo-castle caretakers} 京都, 町家, 寄宿, 二条城, 二条在番

\section{1.はじめに}

江戸時代の京都では町家が上洛武士の宿に供される場合があった。 京都町奉行所（以下、町奉行所）の行政例を記録した『京都御役所 向大概覚書』には、享保元年（1716）に松平讃岐守が将軍名代とし て上洛し、土佐藩邸を宿とする事が決まった時、その家臣のため町 家 150 軒への寄宿要望が町奉行所へ出され、これに町奉行所が町人 との直接交涉を許し、その旨を周辺町々に通知した記録がある注1)。

藤川昌樹氏の研究によれば注2)、江戸時代の京都における同様の寄 宿は幕初の将軍上洛に始まる。随行した各藩は幕府の許可を得つつ 京都藩邸の有無や軍団規模に忍じて自律的に寄宿先を確保、藩主が 社寺・藩邸・上層町家に入ると、家臣は周辺町々の町家や近郊農村 の民家へ寄宿、小屋がけも行い 30 万人以上の宿を確保したという。

その後、将軍上洛は文久 3 年 (1863) まで途絶えたが、将軍名代 や幕府上使の上洛は幾度もあったので、土佐藩邸等その宿の周辺の 町々では、家臣による町家への寄宿が繰り返された可能性が高い。

ところで『京都御役所向大概覚書』は、町奉行所の許可を得た讃 岐守側が直接交涉で先ず町家 200 軒の確保を報告してきたとし、さ らなる選択で 150 棟に絞り込む事を予想している注 3 。 そうすると寄 宿先の町家には何らかの選択基準があった事になり、広く使いや寸 い等が想像されるにしても、江戸時代の京都の町家を受け入れ可否 で分けた選択基準は報告されていない。そこで本論では二条在番の 番衆寄宿の史料を取り上げて、選択基準を含む寄宿形態を検討する。

二条城は寬永 11 年（1634）の家光上洛以降、城主（将軍）不在と なったので、江戸大番組 12 組から毎年 2 組（1 組に石高 5 千 1 万 の大番頭 1 人、600 石、の組頭 4 人・ 200 石の番衆 50 人) が 4 月に
上洛、前任と交代して東西組屋敷や東西番衆小屋に入り、二条在番 を勤めた。寛永 2 年（1625）に二条城代と共に設置された当初の番 衆は 1 組 30 人であったが、家光が上洛した寛永 11 年に 50 人一増員 され、元禄 12 年（1699）の二条城代廃止後は文久 2 年（1862）に京 都守護職設置に伴い二条定番（定員 2 人と与力・同心）が常設され るまで、与力 10 人・同心 20 人を指揮して城内の警衛を続けた注4)。 この二条在番の番衆が、上洛後に前任の退去と交替入城を待つ間、 町家に数日寄宿した。本論は、この番衆寄宿に関する江戸時代後期 の史料から、寄宿を受け入れた寄宿町の拡大過程（2.)、寄宿先の 選択基準 (3.)、寄宿町の負担と費用の分担、寄宿免許との関係 (4.) を検討して、近世京都の町家の実態解明に寄与する事を目的とする。

\section{2. 江戸時代後期の寄宿町の拡大過程}

三条衣棚町（三条室町西入、図 1A） に残る嘉永 6 年（1853）の 冊子『二條御番衆椂御宿此度増町被仰付候一条之事』注5) には、町奉 行所から番衆寄宿について命じられた内容（以下(1) が記される。 東洞院二条下，町年寄長兵衛、其外百九十四町 二条御番衆交代之節、是迄寄宿いたし来町々、近来寄宿相勤候 程之家数追々減少致差支難渋之次第申立、増町之義願出、無余 儀相聞候二付、其方共町寄宿増町申付候間其旨相心得、元寄宿町 申合、町分个致、順番相極、寄宿不差支様致申依請書申付ル（略） 二條御番衆様交代之節寄宿之義、是迄東八堀川通西側迄、西八神 泉苑町通迄、南八松原通、北八御池通上小所迄、此度吟味之上、右 町数之外二東二東洞院通迄、南松原通、北二条通迄 丑三月 寄宿を受け入れていた「元寄宿町」が、「寄宿相勤候程之家」が徐々

\footnotetext{
* 住環境文化研究所 学博

Culture and Life Environment Laboratory, Ph. D.
} 
に減少して「難渋」となったので「増町」を町奉行所一上訴したと あり、これにも町家が寄宿の受け入れ可否で分かれた事が窥える。 なお番衆寄宿が幕初から二条城南側・堀川西側の義務であったのか 明らかでないが、「難渋」は「近来」とあってその可能性は高い。

上訴を認めた町奉行所は瓦之町 (「東洞院二条下町」) ほか 194 町、 合計 195 町を増町に定め、従来の元寄宿町と「申合」を行って「町 分竹」や「順番」を決定するように命じた。元寄宿町は文中の通り名 より二条城南側で堀川西側に位置した事が分る（図 1)。また『慶応 四年改正京町絵図細見大成』(以下、『改正京町絵図』) 注6)では、一 部明確でないが。この範囲に大凡 80 町を数える事が出来る。

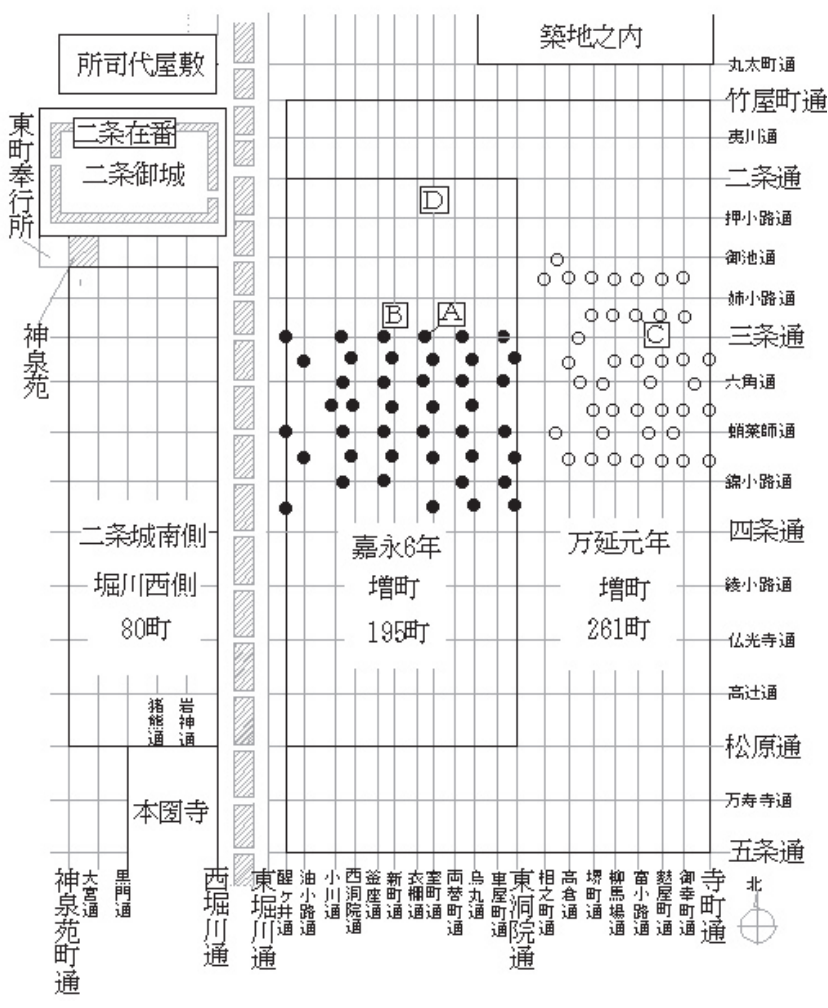

図 1 寄宿町拡大過程（嘉永 7 年寄宿町、○文久元年寄宿町）

嘉永 6 年（1853）の町奉行所の増町命令は 3 月に記録され、毎年 4 月の二条在番交代に伴う番衆寄宿の前月にあたるので、同年は東 洞院通沿いを東限と寸る増町 195 町（図 1）も寄宿町に組み込まれ た事になる。そしてさらに『二條御番衆様御宿、此度増町被仰付候 一条之事』の末尾に「申合」の結果として、「宿割掛町」から三条衣 棚町へ連絡された「順番」が次のように記録されている（以下(2)）。 二条御番衆様御交代之節、御寄宿此度増町被仰付候二付、町分尔 致し順番相定、其順申出候様被仰渡候付、即町分竹順左之通川 二条通帅三条上佃迄・東洞院帅油小路西江入処迄、右町二而壱个 年当丑年御寄宿、三条通归四条上町迄・東洞院归油小路西江入 処迄、右町二而壱个年来 $川$ 寅年御寄宿、四条通归松原上 $ル$ 町迄 - 東 洞院归油小路西江入処迄、右町二而壱个年、来柳年御寄宿、御池 上町归松原通迄・西堀川归神泉苑町迄、右町二而壱个年来辰年 御寄宿、右之通町分竹順相定、一順相済候八、尚又元順之様戻シ 年々順々二御寄宿被為様二相成候間、此段御承知置可被成候
東西は東洞院通沿いから油小路通西入迄、南北は二条通沿いから 松原通沿い迄が増町である。その町数は(1)より195 町であるが、三 条通と四条通で南北に 3 分割されている（図 1、『改正京町絵図』で は北から大凡 62 町、60 町、70 町を数える)。これら 3 組に堀川西側 の元寄宿町と合せた 4 組が右回りに 1 年交代、一巡すればまた最初 からという順番を定めた事が分る（なお東堀川通沿いは増町に入っ ておらず、二条城の対岸にあたる同地は各藩の藩邸が並んでいた事 に関係するのかもしれないが、明らかでない)。そうすると同文書を 残す三条衣棚町は三条室町西入 (図 1A）に位置するから、先ず「寅 年」の嘉永 7 年 (安政元年 1854) に、次回が 4 年後の安政 5 年 (1858) という事になる。そして三条衣棚町の南北両町のうち北町に、嘉永 7 年の番衆寄宿記録（『御番衆様御逗留中日記』、以下(3) がある。

二条御番衆様御宿当寅年町内縄張之内二御座候故、当町内南北分 V有之候故、先番跡番之差別定入置度存、去丑十二月南側千切屋 文右衛門様宅へ出合二テ南側川勝喜平様北側七郎兵衛右三人集会 之上籤取致候処、当寅年北側勤番相当少南側控番二相定り、此次午 年之砌八南側勤番二相当り、其後右之通川順送川順送川相勤番（略） 嘉永 6 年 (1853) の内に嘉永 7 年（1854）の「二条御番衆様御宿」 の「縄張之内」に決まったとあり、(2)と整合する。両町は相談して 北町が「勤番」になり「御宿」を用意・南町は「控番」と決めた。 そして次回の「午年」は南町勤番と定め、確かに戌午の安政 5 年 （1858）に南町における番衆寄宿記録（『二条御番衆様御宿中諸事 控』）がある。このとき南町は、番衆が他寄宿先を訪問する際の案内 用に寄宿町リストを残している (表 1 、『御番衆様宿所控』)。図 1 に ○でプロットすると 3 分割の中段、三条衣棚町周辺に納まっていて 順番を裏付ける。またこれも嘉永 7 年（1854）の記録『御番衆様御 逗留中日記』には、初めて寄宿を受け入れるにあたって前年寄宿先 の蛸薬師町（室町二条下ル、図 1D）から記録借用とあり（「昨年御 破損奉行御宿被勤候蛸薬師町様諸事払書御借致」)、同町は 3 分割の 上段にあって(2)の右回りと整合する。ちなみに三条衣棚町が南北両 町の交代を籤引きで決めた事に他町が関わった形跡はないので、籤 引きは南北別々に町運営を行っていた三条衣棚町内部の交代制度で あって、寄宿町全体の順番には関係がなかったと考えられる。

続いて万延元年 (1860) 3 月にも町奉行所が増町を命じた記録が、 町頭南町（新町三条上小、図 1B）の『御請書』(以下(4) 注7)にある。

武百七拾五町惣代鳥丸四条上 $/$ 町寄仁左衛門其他年寄共

其方共町々二条御番衆交代之節寄宿いたし来所種々難渋申立、 寄宿町増之義願出無餘義も相聞候間、東者寺町通、南者五条通、 北者竹屋町通迄、新規増町申付間申合順二寄宿不差支様致し申候 武百六拾壱町惣代寺町夷川上町年寄新兵衛、其他年寄共 二条御番衆交代之節、是迄寄宿致来沺町種々難渋申立、寄宿町 増之義願出、無餘義も相聞候二付、其方共町々寄宿増町二申付候 間相心得、元寄宿町々申合順二寄宿不差支様致也、尤町々年寄共 呼出申渡不所、多人数之義二付、其方共へ申渡間、右之趣早々町々 ^申通候致也、依而一同請書申付ル

冒頭に記された笋町（鳥丸四条上町）等 275 町が前年（安政 6 年 1859）迄の寄宿町である。これには嘉永 6 年（1853）の増町 195 町 (1) と堀川西側の元寄宿町が含まれる筈なので、堀川西側の町数 
表 1 安政 5 年の寄宿町（寄宿有は○、無は一）

\begin{tabular}{|c|c|c|c|c|c|}
\hline 住所 & 建物 & 先跡 & 住所 & 建物 & 先跡 \\
\hline 三条東洞院西入 & 会所 & $0-$ & 蛸薬師烏丸西入 & 会所 & ০০ \\
\hline 室町三条通下 & 会所 & ○০ & 三条烏丸西入 & 会所 & O০ \\
\hline 東洞院三条通下i & 居宅 & ○० & 西洞院六角下V & 居宅 & O० \\
\hline 烏丸蛸薬師通下r & 居宅 & ০০ & 六角西洞院西入 & 居宅 & O০ \\
\hline 錦小路東洞院通下 $\mathrm{r}$ & 居宅 & 00 & 油小路錦小路下i & 居宅 & O० \\
\hline 新町三条通下r & 会所 & ০০ & 室町四条下ル & 居宅 & $0-$ \\
\hline 炭屋図子町 & 居宅 & ০০ & 蛸薬師西洞院西入 & 居宅 & ০০ \\
\hline 新町三条下 $r$ & 居宅 & o- & 小川六角下ル & 居宅 & ০০ \\
\hline 蛸薬師東洞院西入 & 居宅 & ০০ & 錦小路西洞院西入 & 居宅 & ০০ \\
\hline 烏丸通三条下儿 & 会所 & ○০ & 醒ヶ井錦小路下V & 会所 & ০০ \\
\hline 三条室町西入 & 居宅 & O০ & 烏丸錦小路下ル & 会所 & 00 \\
\hline 六角烏丸西入 & 会所 & $\infty \circ$ & 蛸薬師油小路西入 & 居宅 & ০০ \\
\hline 錦小路新町西入 & 会所 & ০০ & 室町蛸薬師下 $N$ & 居宅 & $0-$ \\
\hline 三条新町西入 & 会所 & ০০ & 烏丸六角下r & 町持 & o- \\
\hline 蛸薬師新町西入 & 居宅 & o- & 三条西洞院西入 & 居宅 & $0-$ \\
\hline 六角東洞院西入 & 居宅 & $\infty \circ$ & 西洞院蛸薬師下i & 居宅 & -0 \\
\hline 三条油小路西入 & 町持 & ○० & 蛸薬師室町西入 & 居宅 & -0 \\
\hline 東洞院錦小路下i & 居宅 & 00 & 六角新町西入 & 居宅 & -0 \\
\hline 錦小路烏丸西入 & 会所 & ০০ & 越後突抜町 & 居宅 & $-\circ$ \\
\hline 新町六角下N & 居宅 & ○० & 西洞院三条下， & 居宅 & $-\circ$ \\
\hline 新町蛸薬師下 $r$ & 会所 & ○० & 六角室町西入 & 会所 & $-\circ$ \\
\hline 油小路六角下 & 会所 & ০০ & 油小路蚂薬師下i & 会所 & -0 \\
\hline 東洞院蛸薬師下i & 居宅 & $\bigcirc \circ$ & 油小路三条下 & 居宅 & -0 \\
\hline 油小路三条下 & 居宅 & ০০ & 室町六角下 $N$ & 会所 & -0 \\
\hline
\end{tabular}

は 275 町-195 町=80 町となり、『改正京町絵図』に数えた町数とも一 致する。堀川東側の 3 分割に数えた 62 町、60 町、70 町と比べれば 10〜20 町も多いが、寄宿可能な町家の減少を訴えた堀川西側では受 け入れ可能な町も減って (1) 嘉永 6 年には 60〜 70 町になっていて、 この数が後の増町の参考とされたのかもしれない。

そして嘉永 6 年から番衆寄宿が右回りに始まって 2 順目の最後、 堀川西側の番となった万延元年（1860）に再び上記増町が命じられ た。(3)の後段冒頭より増町は東が寺町通迄、北は二条通を超えて上 京の竹屋町通迄、南が五条通迄、寺町夷川上ル町 (久遠院前町か藤木 町）等 261 町に広げられた。ところが西側は設定が記されない。そ こで(2)が東限とした東洞院通の東入を増町西限と仮定寸ると、『改正 京町絵図』では大凡 185 町を数えて 261 町に大きく足りない。それ では(2)が嘉永 6 年の増町西限とした油小路通西入を増町西限とする と、竹屋町通より北側に 37 町、松原通より南側に 38 町を数え、185 町 +37 町 +38 町 $=260$ 町となって(4)の 261 町と整合する。このため 万延元年 (1860) の増町は嘉永 6 年の増町を取り囲むように拡大設 定された可能性が高く（図 1)、寄宿町の総数は 275 町 +261 町 $=536$ 町となった。この数は元寄宿町の堀川西側 80 町から 7 倍近くになる。

なお福長町（富小路通三条通上儿、図 1C）には、文久元年（1861） の番衆寄宿記録と寄宿先リストがある注8)。その寄宿先を図 1 に○で
プロットすると、南北が御池通下ルから錦小路通上ル、東西が東洞院 通東入から寺町通迄となる（御池通沿いが高倉通西入 1 町だけの理 由は明らかでない)。これに万延元年以前の右回り順（4) を考え合 わせると、万延元年増町後もこれに沿った「町分ケ」や「順番」が想 像される。しかし実は福長町の寄宿先リストには 43 人しか記されず、 1 組 50 人 $\times 2$ 組 $=100$ 人の番衆定員の半分にも足りない。そうする と同年は他の町々にも番衆寄宿があった可能性もあるが、万延元年 増町の「町分尔」や「順番」が明らかでなく検討出来ない。また文久 2 年 (1862) 8 月には尊攘派の暗殺活動に対応すべく京都守護職が設 置され、二条定番は常設となって（1.) 交代入城を待つ間の番衆寄 宿もなくなった。万延元年の順番が回ったのは 3 回、3 年間であっ た。但し廃止翌月の 9 月に、次の文書が町代からもたらされている。

上者今出川、下者五条、東者寺町、西者御土居、右之方角之内、

寺院并町方共建物間取数十間以上有之家之分、別紙之振合二相認 書出候様被仰出候（略）

文久 3 年（1863） 3 月の将軍家茂上洛を控えて「十間以上」の寺 院や町家を鴨川西側に広く求めている。番衆寄宿の選択条件であっ た 5、6 室に倍する規模であり、幕初から約 230 年、再び政治の表舞 台となった京都で寄宿先の必要性が増した事が分る。三条衣棚町の 記録『御寄宿之控』にも慶応 2 年（1866） 10 月 16 日〜 11月 7 日に 幕府の「御徒目附」が、 11 月 12 日〜 12 月 12 日に「陸軍付調達役」 が寄宿した記録があり、さらに「組合町々申合、有合品々を如何様 共いたし差支無之様」と記されている。この「組合」が万延元年の 「町分ケ」や「順番」を受け継いだ可能性もあるので、二条在番廃止 後の上洛武士による寄宿史料のさらなる収集が今後の課題である。

以上、番衆寄宿の寄宿町は長く二条城南側・堀川西側の 80 町が務 めていたが、寄宿可能な家の減少で町奉行所一上訴、これを認めた 町奉行所は嘉永 6 年（1853）に堀川東側の 195 町を寄宿町に組み込 んだ。合計 275 町は 4 組に分かれて 4 年に 1 回ずつ、右回りの順番 で番衆寄宿を務めた。万延元年（1860）にも再び増町が命じられ、 261 町を加えた 536 町が寄宿町となったが、新しい順番は明らかで なく、3 回の番衆寄宿を受け入れた後の文久 2 年（1862）に二条定 番が置かれて番衆寄宿はなくなった。但し幕末の京都では上洛武士 の寄宿先の必要性は増しており、町々への寄宿も続いていた。

\section{3．番衆寄宿のため町が用意すべき町家}

番衆寄宿先の選択基準は、(1)に「寄宿相勤候程之家数」とあった が、先にも取り上げた三条衣棚町の嘉永 7 年（1854）の『御番衆様 御逗留中日記』にも次のように記されている(以下(5)）。

三月七日迴章参り、此度二条様御番衆御宿、縄張之内二御座候間、

五六間以上之建家、一町内二本宿一軒、控宿壱軒川、御書出（略）

当家名前建家図面認义、来忛日迄二御差図可被成候（略）

寄宿町に定まった三条衣棚町が町奉行所から触書（「迴章」）で命 じられた内容は、「本宿」と「控宿」として「五六間以上之建家」を 選び、その「建家図面」を提出する事であった。これに先ず番衆寄 宿の町家には町側の選択と町奉行所の確認が読み取れるが、記され た「五六間」が建物間口の間数か、部屋数 (間取数) なのか、この 点について同町に文久元年（1861）の以下文書がある (以下(6)。 
御番衆様御宿相勤候御時、家建間数之儀取調心゙候様被仰渡候間、 左之通奉申上候

一、玄関何帖、表之間何帖、次之間何帖、奥之間何帖、勝手向 之間何帖、何屋何兵衛宅

一、玄関何帖、表之間何帖、次之間何帖、奥之間何帖、勝手向 之間何帖、町中会所家

外二控御家、四間以上、右者町中之内二而相勤申候、何組何通何 小路上ル下ル西入東入、何之町、年号月 年寄誰印

番衆寄宿に用いた町家の間取りと帖数を報告する際の案文である。 これに基づき三条衣棚町は、同年 5 月に「玄関六帖、表間十一帖半、 次間六帖、奥間十二帖、勝手向間九帖、千切屋吉右衛門居宅、玄関 四帖半、表十七帖、次間九帖、奥間十八帖、勝手向間十三帖半、千 切屋次兵衛居宅、外二控御家、四間以上、右者町中之内二而相勤申候」 等と記寸文書を「御年寄様」へ提出した(「御年寄様」が町組か、䊍 町か、どちらに属するのかは明らかでない)。このやりとりをみると、 番衆寄宿の町家には間取りと帖数が重要であった事になり、(5)の「五 六間以上之建家」は5、6 室以上の間取りを持つと考えられる。

また(5)には「但泫関無之向者書出し二不及候、認娠案紙之通师二テ 壱町分二四五軒御書出し又八右無之候八、壱武軒二而も不苦」と記す付 箋も付いており、玄関も不可欠であった。そこで三条衣棚町は町家 2 軒について玄関を含む 5 室の帖数を報告したと考えられる。

以上、番衆寄宿のために町が選択すべき町家は、床上の間取りが 5、6 室以上、その中に玄関があり、他は表間、次間、奥間、勝手向 間という構成が必要であった事になる。これが番衆寄宿の必要条件 すなわち町家の選択基準と推測されるので、実例で裏付けるために 史料を探すと、文久元年 (1861) の福長町（図 1C）の「御用達宿 近 江屋吉太郎」の居宅平面図がある（図 2)。1 階床上が「みせ」以外 に 7 室あり、玄関は「上口」が付く 9 帖に推定され、上記の選択基 準を満たしている。三条衣棚町も嘉永 7 年（1854）の番衆寄宿に用 いた町家に関して『御番衆様御逗留中日記』に以下を記す(以下(7))。

門内一統集会之上、相談仕候得共、兔角外之様二八御宿出来候宅 も無御座候故、西村様御両家入御願申候、然几処右何連様共定入 難 $力$ 候間、右両家籤取二致貴、当寅正月七郎兵衛宅二テ吉右衛門様 · 文右衛門様御立会二广籤取極入申候処、当年吉右衛門へ相当り申候

故、西村吉右衛門様御宅借り請相勤申候

「門内一統集会」は木戸門内側つまり南北両町の家持全員の相談を 意味し、これで「御宿」候補を「西村様御両家」に定めた。さらに 籤引きで西村吉右衛門居宅を選んでおり、先述の文久元年 5 月報告 にも「千切屋吉右衛門居宅」としてその名があった。尤も三条衣棚 町が文久 2 年（1862）11 月に町奉行所へ提出した文書『寺院并町方 建物、間取数十間以上有之分尋二付届書』には、西村吉右衛門居宅と して法衣商売の西村吉右衛門ほか「家内壱人、召仕十一人」が住む 同居宅の室名と帖数が以下のように記されている (以下(8)。

七間 表間十一帖半、格子間六帖、玄関六帖、次之間六帖、奥 間十二帖、上台所五帖、下同九帖、西之方離間六帖・雑物入 二階五間、表間十六帖、東間八帖、奥間十一帖半、次之間八帖、 下台所八帖、内二帖板間

8)の内容は、文久元年 5 月報告より詳細な情報を伝えている。

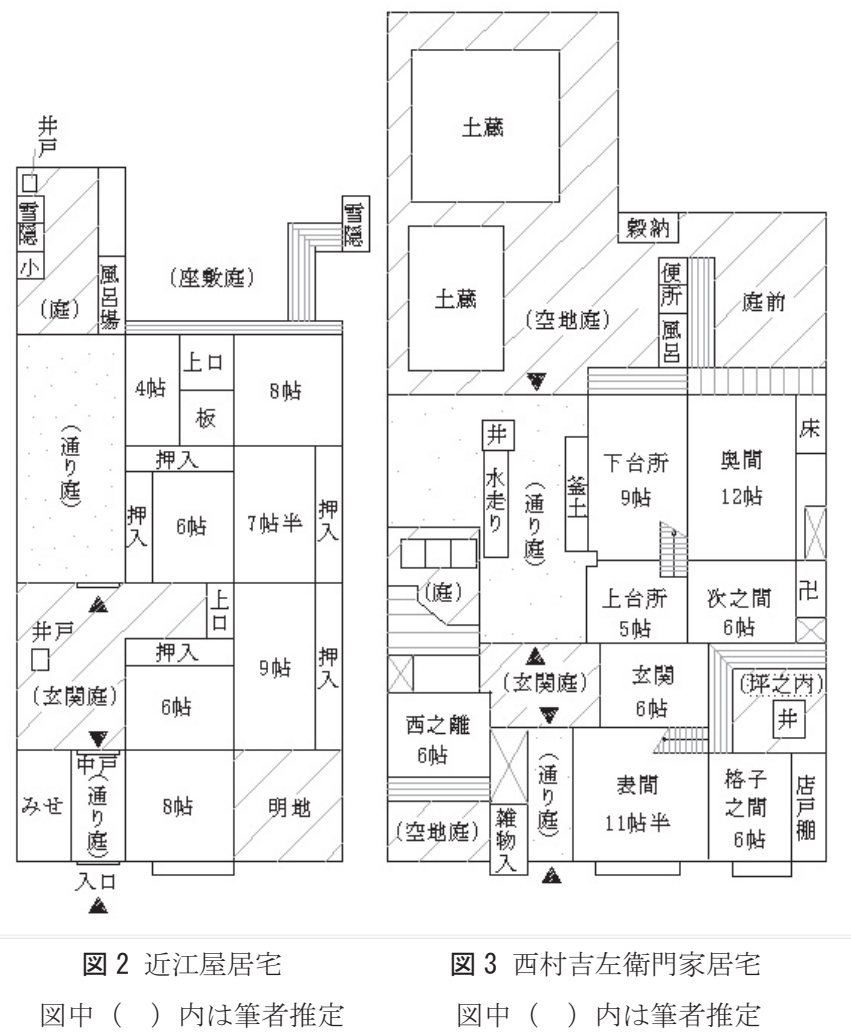

1 階床上は玄関を含む 7 室で 2 階は 5 室、合計 12 室となる。する と文久元年 5 月の報告は 2 階を記さず、 1 階も上台所 5 帖と格子之 間 6 帖を省いていた事になるが、(6)案文に従ったためと思われる。

この西村吉右衛門家には野口獄氏による精緻な研究があり注9)、弘 化 4 年～元治元年（1847-64）の居宅平面図も復原されている。これ を参照しながら 8 より室名や帖数を書き込むと図 3 になる。「西之 離」以外は動線的に強く結び付いており、文久元年 5 月報告で省か れた上台所 5 帖之格子之間 6 帖も番衆寄宿に供された可能性が高い。 そうすると番衆寄宿中の西村吉右衛門ほか家族等 12 名の居場所が 問題となるが、この点は安政 5 年の寄宿先リストを参照したい（表 1)。居宅以外の会所が 17 棟、町中持家が 2 棟あり、合計 19 棟は全 48 棟の 4 割を占める。髪結が入り込む場合が多かったとされる会所 や無住の町中持家も注10)、(6)第 2 項が会所に報告を命じていたように、 玄関を含む間取りの選択条件を満たせば番衆寄宿に用いる事が認め られていた。その場合、番衆寄宿に関わる労働力は町側が用意・提 供した筈だから、居宅の町家を寄宿に提供した町家持主も、寄宿中 は家族等と共に別の場所へ移っていた可能性が高い。それには当然 金銭的負担が予想されるが、それを誰がどのように分担したのか。 ほかにも番衆寄宿に伴う負担や費用分担があり、次節で検討する。

以上、寄宿町は番衆寄宿のため 1 階床上に $5 、 6$ 室以上、玄関は不 可欠で表間、次間、奥間、勝手向間も備えた町家用意の必要があり、 選択基準として町中から選しだ。但し選択条件を満たせば会所や町 中持家でもよく、むしろ住人移動の必要がそれらは積極的に用いら れた可能性もある。尤も三条衣棚町が『御番衆様御逗留中日記』に 「当町内会所二而ノ御宿出来不申」と記したように、選択条件を満た ない会所や町中持家は当然の事ながら用いる事は出来なかった。 


\section{4. 番衆寄宿に伴う寄宿町の負担と分担}

三条衣棚町の南北両町は、番衆寄宿の手順を記す『御番衆様御寄 宿御勤方相心得覚』(以下『心得覚』) をそれぞれ保有した。両町が 所属する「下古京上艮組」の名前で「今般格別間遠勤番相迴候義二 付町々往前之者も追々品替り二成行候間、前々之通町々しかと控置

(略) 不同無之様相勤趣之御沙汰」と記され、嘉永 6 年（1853）の 増町で 4 年に 1 度（町運営が南北に分かれた三条衣棚町は内部的に 8 年に 1 度）の番衆寄宿となった組内町々に「不同無之様」のため 配布された事が分る。したがって番衆寄宿の一般的形態と判断され、 本節ではこの『心得覚』と、三条衣棚町が初めて番衆寄宿となった 際の『御番衆様御逗留中日記』(以下『逗留日記』)、安政 5 年 (1858) の南町の番衆寄宿となった際の『二条御番衆様御宿中諸事控』(以下 『宿中諸事控』）を照合して番衆寄宿の負担内容と分担を検討する。 先ず『宿中諸事控』から、安政 5 年正月 27 日に町奉行所配下の町 代から「当年八御番所様御宿御勤番二付、当家之絵図面、当月中二广差 出」との連絡を受けた南北両町は、嘉永 7 年から 4 年ぶりの番衆寄 宿について 2 月 1 日に町内家持全員が相談。「当年八南町之番」とし て南町の「西村妙教様」居宅を寄宿先に選び借りる事を決めた(「御 宅御拝借申上二極入）。そして北町が選んだ「控宿」と共に「絵図面」 を用意して町代一提出、2 月 13 日に町代が下見に来た。 3 月 4 日と 同月 26 日には東町奉行所からの召喚があり、4 日に出向いた町役人 は「御番衆様御宿請書」の提出命令を受けたので 26 日に提出した。

4 月 1 日には町内全員で「御逗留中入用遊す道具」を確認したが、 『逗留日記』に「御客入用家具其外少々之入用品 1 西之洞院下立売 上ル柲屋源七殿二而借り受け（略）夜具類も右同断」とあるので、不 足道具や寝具等は、他町の貸物業者から借用したと思われる。4月 7 日には町内家持全員が西村妙教居宅一出向いて「御道具相調え、并二 座敷廻り本飾付」を行う。この飾り付けの内容も『心得覚』に次の ように記されていて、寄宿町共通の仕様であった事が分る。

飾付 掛物、但目出度図、且朔日掛変之事、三宝尉斗・昆布、 刀掛、毛勯、床花、天目台并茶碗・御茶、多葉袴盆、但し灰 吹青竹、外二御客来有之節差出候多葉袴盆式ッ余

御居間 綺麗なる座敷処、御具足下敷 綿緞通、屏風、高杯、座 布団、鑓掛、殿様湯衣、手拭掛

湯殿便所成丈ケ綺麗いたし置候事、手洗い朝場二楊枝・毛剃受、 日及御月代被遊候二付用意之事、湯殿 手拭ぬか袋茶碗之湯

次之間 御用人・御家来 たば古盆用意いたし置事

同じ 4 月 7 日、先番の番衆に「御宿」を「御引渡」する前の事前 検查として「御見分役人」来訪が町代から予告される(「明八日五” 時迄二番椂御宿御引渡為、御見分御役人中御出被成候」)。これにより 番衆寄宿の町家は、町内家持全員で選択、持主から借りて飾り付け、 町奉行所による事前確認を経て、番衆へ引き渡された事になる。

続いて主に『心得覚』から、番衆が到着して以降の経緯をみる。

到着予定 御先番御殿様四月十一日御上着、右御入城十三日、御 先番御跡登御殿様四月十二日御上着、右御入城十四日（略） 御跡番御殿椂四月十三日御上着、右御入城十五日（略）御跡 番御跡登御殿様四月十四日御上着、右御城入十六日

先番にも跡番にも「御跡登」がいるので、到着は 4 期に分かれた
事が分る。しかし『宿中諸事控』では先番として番衆の旗本「多門 鎌之助様」ほか御用人・侍・中間 2 人つまり上下 5 人が 4 月 11 日午 後 7 時（「夜五ッ半」）到着 $\rightarrow 13$ 日午前 3 時（「朝七ッ半」）入城。続 いて跡番の番衆旗本「松本蔵之助様」ら 5 人が同 13 日午後 8 時 (「朝 五ッ時」）到着 $\rightarrow 15$ 日午前 3 時（「朝七ッ半」）入城とあり、先番 1 名と跡番 1 名、合計 2 名の寄宿である。これは他の寄宿町にも共通 するので（表 1)、到着は 4 期に分かれても 1 町の番衆寄宿は先番と 跡番の 2 名が基本であったと判断される。また寄宿期間は 2 泊 3 日 で到着から 2 日後の入城も『心得覚』と整合するが、先番が去って から跡番が入るまでは 5 時間しかない。実質的には 4 月 11 日夜〜 15 日早朝の 4 泊 5 日間、町家内部に常に 5 人が滞在して、その食事や 入浴等の用意、掃除や片付が連続的に必要であった事が窺える。

なお、万延元年（1860）増町を経て文久元年（1861）の寄宿町に なった福長町には 4 月 12 日の 1 人しか記録されない (2.)。同年の 寄宿先リストには 4 月 11 日到着が 21 町、 4 月 12 日到着が 20 町、 合計 43 人の寄宿先があるが、間は 1 日しかなく、先番と跡番とは考 え難い。それよりも到着が 2 期に分かれた先番の可能性が高く、同 年の跡番の動向は、万延元年設定の順番と共に今後の課題である。

以上、番衆寄宿の一般的形態は上記の福長町の例ではなく、『心得 覚』と『宿中諸事控』が整合した三条衣棚町の安政 5 年の例に推定 される（嘉永 7 年『逗留日記』は二条破損奉行ら上下 8 人が 4 月 6 日夕方〜 13 日朝の 8 泊 9 日寄宿を記す。これは同 6 日の御所出火に 始まった大火「毛虫焼け」の影響で交代が遅延したためと思われる)。

宿札配布 · 掲示 · 出迎え 御殿様御宿札并御人数御目録書、町代 帅御渡被相成、御殿様御着候迄奉差上可候事（略）御殿様御宿 札相掛候如此之札被渡置候事 (図略)、但板へ張置、門入御掛置候

事、尤夜分御仕舞之節者、高折へ掛置候事（略）夜分当家之門 口釣提灯差出し候事、御殿様御名前書記張置事

番衆の到着前に、誰が何人寄宿寸るか、目録と宿札が町代から町 組を通して寄宿町に届くとある。『宿中諸事控』でも町奉行所の事前 検査後に「町代衆寄場」で宿札を受け取り、板に張って寄宿中の日 中は門に掛け、夜間は取り込み代わりに番衆の名前を記した提灯を 門口に釣ると記す。また『心得覚』は、到着日は町側が寄宿番衆の 名前を記した板を掲げて早朝から出迎え、町家へ到着した際は裃姿 の町役人と羽織袴の町家持主に出迎えを定める（「年寄裃上下二而門 口迄御出迎、并宿主者羽織袴二而同断之事」)。番衆が座敷で着座する と次之間から規定の口上 (「御道中御機嫌良御着被遊、恐悦至極奉存 候」) で「丁寧二御挨拶」を定める。町家持主が記されるのはこの「御 目見え御挨拶」だけで、後は町が用意した年少者が世話をし(「其余 之給仕小用之義者十四、五才斗之者二羽織袴」）、町が饗応を行き届か せ（「御殿様夜分御酒肴等之義臨機応変二程能取斗」「珍敷品折々二差 上候様いたし候得者都合よき」)、番衆の外出時は町役人の案内（「御 殿様外方へ御出候節者御案内」）まで定める。また福長町は『出勤役 割』に「座敷殿様取持二人、付添一人、表間・中間取持二人、三条 寺町御迎四人、蹴上迄御出迎四人、下働之者二人、下小使働之者二 人、惣取締後見一人御役中、外二料理人ひかきや、道具洗い方二人、 茶番、酒之間方」をあげており、料理人以外の延べ 23 人は町内労働 力と思われ、ここでも町家持主や家族等は他へ移った事が窥える。 
なお料理人が調理する食事は『心得覚』に到着日の「御着祝酒・ 御膳・夕食」から中日の「朝飯・昼飯・夕飯」、入城日の「朝飯・御 弁当」まで、品数・献立が細かく定められる。味付けも「江戸子八 白味噌汁者不用甚不機嫌、何分赤味増」等と注意が促され、酒も「何 卒本伊丹精々宜敷御吟味」と伊丹産推奨の付箋が付いている。因み に『宿中諸事控』は入城日の差し入れ弁当を外注と特記するので(「御 昼弁当城内^差入、神泉苑町鉡助方へ申付」)、上記食事は福長町同様 に料理人を雇って寄宿先での調理が一般的であったと推測される。

このほか『心得覚』は、到着日の風呂の用意 (「何時御着之程も難 計候間、風呂場第一早々わかし置」) や入城前夜の寄宿先での終夜待 機も御迷惑と注意している(「朝七っ時二御出立被遊候間、何連夜通 沪致居候而者御差支二相成候間、此儀しかと相心得」)。

以上、番衆寄宿は町内町人の実働で多くを補ったが、寝具等の諸 道具は外部から借用した。料理人の手配や食材・酒の調達、町家持 主の移動にも金銭的負担の発生が推測される。そこでこれらを誰が 負担したのかが問題となるが、この点について『逗留日記』には、 嘉永 7 年の番衆寄宿後に三条衣棚町は町奉行所から「二条御番御宿 町御逗留中御賄料」や「差出し物等取調」を命じられ、「殿様御賄、 同御下七人様、上之分夜具・同下之分」として町奉行所内の町代部 屋の「宿割掛」へ銀 184 多 1 分 6 厘を報告、 5 月 12 日に報告相当の 金 2 両 2 歩 2 朱 510 文が「御賄料入」とする。前述のように同年は 8 泊 9 日分で一般的な 4 泊 5 日分の倍額にあたる可能性が高いが、 とにかく寄宿町の負担費用は、町奉行所配下の町代を介し寄宿町以 外の町々へ割り当てられた事が窺える。この点に関して万延元年

（1860）の増町を伝えた『御請書』(4)）にも以下が記されている。

（略）宿可勤家建無之町々之向者不相勤儀を当然之事二相心得居 候様二而者不相当二付、是迄寄宿相勤来候町々惣代共归申立候通

（略）宿相兼町々順番二組合不可成とも、平等二無懈急相勤候様 いたさせ、依而寄宿町々もの共一同、請書申付ル（略）

町奉行所は、町内に番衆寄宿の選択条件にあう町家がないとして 「順番」に加わらない町が「当然」と考える事を「不相当」とし、 「平等」の負担を命じている。そうすると、これ以前は寄宿町であ りながら選択条件に合う町家がないとして番衆寄宿を回避した上に、 割り当ても受けない町が存在した事になり、その増加が堀川西側の 町々の難渋や上訴、増町の理由に推測される (1))。つまり番衆寄宿 の負担費用の割り当てが寄宿町以外の町々へ行われていた事が窺え るのであり、町奉行所が命じた平等とは、割り当て免除の寄宿町で あっても回避した町は割り当てを徹底する意味であったと思われる。

また京都には御所から「諸役免除札」「寄宿免許札」を付与され、 町人義務を「免除」、寄宿を「免許」される朝廷関係者や御所御用達 がいた注11。ここで「免許」が「許可する事」なら寄宿免許は寄宿受 け入れの許可であるが、『京都御役所向大概覚書』が「諸役寄宿御免 許之義」つまり「諸役」「寄宿」共に「御免許」としながら文中では 「諸役免許」「寄宿免除」とするので (「諸役免許之初者後陽成院御 治世帅初り、夫归以前者寄宿免除計被下候由」）免許は免除と同じ意 味である注12)。「諸役寄宿御免許之義」は「諸役免除之分」と「寄宿 御免除之分」を 331 人あげており、彼らは住まいを選択対象から外 されただけでなく、負担費用の割り当ても免除されたと考えられる。
以上、番衆寄宿の町家は町が選び、持主の町人から借りて諸道具 の用意や飾付等も行った。そして町奉行所の事前確認を受け、御宿 として引き渡し、普通は 4 泊 5 日間、町側が世話をして町家持主や 家族等は別の場所へ移っていた。金銭的負担は寄宿町以外に割り当 てられたが、万延元年からは条件に合う町家がないとの理由で受け 入れを回避した町にも割り当てられた。他方、御所から諸役や寄宿 の免除札を付与された者は、選択対象から外された可能性が高い。

\section{5. 本論のまとめ}

・ 二条在番の番衆寄宿は二条城南側で堀川西側 80 町が相当期間 務めたが、選択基準を満たす町家の減少を理由に回避する町が 増加、他町の負担が大きくなったので嘉永 6 年 (1853) に上訴、 堀川東側 195 町が増町に定められた。合計 275 町は 4 組に分か れ右回りに 4 年に 1 回の番衆寄宿という順番を定めたが、万延 元年に再び増町となり、嘉永 6 年の増町周辺の 261 町を加えて 合計 536 町となった。その順番は文久 2 年 (1862) の二条在番 廃止迄に 3 回機能した筈であるが、内容は明らかではない。

・当時の町家の選択条件は、 1 階床上に $5 、 6$ 室以上、玄関があっ て表間・次間・奥間・勝手向間もあり、風呂や便所も備えた町 家であった。この選択基準に合う、合わないで寄宿町の町家は 二分されたが、条件を満たせば会所や町中持家も利用出来た。

- 番衆寄宿先の町家は町が選択、町家持主から借り、寝具や諸道 具も用意して飾り付けを行った。そして町奉行所の事前検査を 経て先番跡番 2 名の番衆へ御宿として引き渡し、4 泊 5 日が基 本の寄宿期間中は町が労働力を提供して入念に世話を行った。

- 番衆寄宿に伴う金銭的負担は、町代を介して寄宿町以外の町々 へ割り当て、万延元年からは寄宿町にありながら回避していた 町にも割り当てられた。但し御所から諸役免除や寄宿免許の木 札を付与された朝廷関係者や御所御用達は住まいを選択対象 から外され、負担費用の割り当ても免除された可能性が高い。

注1）京都御役所向大概鸴書，上巻「三十将軍宣下相済候二付、為御名代松平 讃岐守殿御登之節勤方之事」より「松平讃岐守殿今度上京二付、右之内 下宿借宅仕度旨家来菅彦助申出候二付、勝手次第之旨申聞候、尤右町中 江も申渡候事」，清文堂史料叢書，第 5 刊，清文堂，1973

注2）藤川昌樹：近世武家集団と都市・建築，中央公論美術出版， 2002

注3）上掲注 1）上り「余慶分者追而被除積と奉存候」

注4）国史大辞典, 第 10 卷, 二条在番, 吉川弘文館, 1990

注5）京都府立総合資料館蔵, 三条衣棚町文書, 本文中の他の同町文書も同じ。

注6）京都府立総合資料館蔵

注7）京都府立総合資料館蔵，町頭南町文書（乙）

注8）京都府立総合資料館蔵, 福長町文書, 本文中の他の同町文書も同じ。

注9）野口徹：日本近世の都市と建築, 法政大学出版, 1992

注10）西川幸治：日本都市史研究，日本放送出版会，1972

注 11）丸山俊明: 京都の町家の軒先板の再検討, 日本建築学会計画系論文集, 第 634 号, pp2747-2754，2008.12

注 12）清文堂史料叢書 5 刊, 京都御役所向大概鸴書, 上巻, 清文堂, 1973 